\title{
Editorial 46
}

\author{
Eric R. Scerri
}

Published online: 28 March 2014

(C) Springer Science+Business Media Dordrecht 2014

This issue begins the sixteenth year of our publication. It consists of the second part of the special issue dedicated to the late Richard Bader and edited by Cherif Matta one of his former students. For an extensive editorial covering the contents of both parts of the special issue readers should consult issue 3 of volume 15 . $^{1}$

I would like to mention two recent items that may be of interest to readers. The first is that Lee McIntyre and I have been asked by the publisher Springer to edit a second edition of our book that first appeared in 2005 . $^{2}$ The new edition is almost ready and contains contributions from many well-known philosophers of chemistry as well as some relative newcomers. They are Marina Banchetti-Robinho, Joseph Earley, Grant Fisher, Rom Harré, Hinne Hettema, Jean Pierre Llored, Olimpia Lombardi, Farzad Mahootian, Alexander Manafu, Paul Needham, Klaus Ruthenberg, Joachim Schummer and Pieter Thyssen together with Koen Binnermans.

The second announcement concerns the 18th annual international meeting of our society that is to be held at the London School of Economics, from Monday-Wednesday, 7-9th July 2014, in the Lakatos Building (LAK 2.06). The organizer Rom Harré tells me that there will be a number of invited speakers including Sir Paul Nurse the Nobel Prizewinning biochemist and a president of the Royal Society since 2010. For further details about the conference including submission deadlines, travel details, registration etc. please see, http://www.lse.ac.uk/CPNSS/events/Conferences/ispc2014.aspx.

\footnotetext{
${ }^{1}$ C. Matta, Special issue: Philosophical aspects and implications of the quantum theory of atoms in molecules (QTAIM), Foundations of Chemistry, 15, 3, 245-251 (2013).

2 The Philosophy of Chemistry: The Synthesis of a New Discipline, Baird, D., Scerri, E.R., McIntyre, L. (eds.), volume 242 of Boston Studies in the Philosophy of Science, Springer, Heidelberg, 2005.
}

\section{E. R. Scerri $(\square)$}

Department of Chemistry and Biochemistry, UCLA, Los Angeles, CA 90095, USA

e-mail: scerri@chem.ucla.edu

URL: http://www.ericscerri.com 
The following is a complete list of previous meetings;

\begin{tabular}{lll}
\hline Location & Year & Organizer \\
\hline Ilkley, UK & $(1997)$ & Michael Akerod \\
Cambridge, UK & $(1998)$ & Michael Akeroyd \\
Columbia, SC, USA & $(1999)^{*}$ & Davis Baird \\
Poznan, Poland & $(2000)$ & Ewa Zielonaka-Lis \\
Loughborough, UK & $(2001)$ & Tony Edmonds \\
Washington, DC, USA & $(2002)$ & Joseph Earley \\
Tartu, Estonia & $(2003)$ & Rein Vihallem \\
Durham, UK & $(2004)$ & Robin Hendry \\
Knoxville, TN, USA & $(2005)$ & Jeffrey Kovac \\
Split, Croatia & $(2006)$ & Hrvoj Vancik \\
San Francisco, CA, USA & $(2007)$ & Tami Spector \\
Coburg, Germany & $(2008)$ & Klaus Ruthenberg \\
Philadelphia, PA, USA & $(2009)$ & Michael Weisberg \\
Oxford, UK & $(2010)$ & Rom Harré \\
Bogota, Colombia, & $(2011)$ & Guillermo Restrepo and José Luis Villaveces \\
Leuven, Belgium & $(2012)$ & Pieter Thyssen and Brigitte Van Tigglen \\
Montevideo, Uruguay & $(2013)$ & Lucia Lewowicz \\
\hline
\end{tabular}

* The first volume of Foundations of Chemistry appeared in 1999 